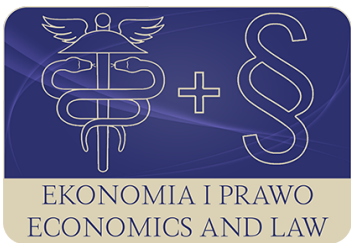

EKONOMIA I PRAWO. ECONOMICS AND LAW

Volume 19, Issue 1, March 2020

p-ISSN 1898-2255, e-ISSN 2392-1625

www.economicsandlaw.pl

ORIGINAL ARTICLE

received 30.03.2019; revised 13.12.2019; accepted 31.03.2020

Citation: Krawczyk, P., \& Kokot-Stępień, P. (2020). The impact of the exchange rate on the financial result of enterprises in the transport sector. Ekonomia i Prawo. Economics and Law, 19(1): 47-60. doi:10.12775/EiP.2020.004.

\title{
The impact of the exchange rate on the financial result of enterprises in the transport sector
}

\author{
PATRYCJA KRAWCZYK \\ corresponding author \\ Czestochowa University of Technology, Faculty of Management, Department of Finance, Banking \\ and Accounting, ul. Dąbrowskiego 69, 42-201 Częstochowa, Poland \\ $\square$ patrycja.krawczyk@wz.pcz.pl \\ DiD orcid.org/0000-0002-3814-4603

\section{PATRYCJA KOKOT-STĘPIEŃ} \\ Czestochowa University of Technology, Faculty of Management, Department of Finance, Banking \\ and Accounting, Poland \\ $\square$ patrycja.kokot-stepien@wz.pcz.pl \\ (D) orcid.org/0000-0001-7222-0369
}

\begin{abstract}
Motivation: Transport is one of the most important elements that have a major impact on economic development in various countries around the world. Among the main factors that affect the evolution of transport is the development of consumerism, globalization, as well as the modernization of road infrastructure. There are more and more transport com-

panies on the market, which is supported by the dynamic pace of life and the provision of services in the shortest possible time, at the lowest possible price. Therefore, transport companies are a very important economic link. Many factors affect their economic condition, one of them being the exchange rate.

Aim: The aim of the article is to show the relationship between exchange rates and financial results of Polish enterprises in the transport sector. The analysis will show the profits and costs in relation to the exchange rates (Zloty to the Euro, US Dollar, British Pound

and Swiss Franc). The expected research period will cover the years 2010-2017.

Results: The basis of the conducted analyzes will examined the dependence of the financial result (including revenues and costs) on the exchange rates (USD/PLN, EUR/PLN,
\end{abstract}




\section{GBP/PLN, CHF/PLN). \\ Keywords: correlation; exchange rate; financial result; transport industry JEL: R40; C58; F31}

\section{Introduction}

Transportation plays a broad role in shaping economies. Transportation supports clusters and agglomerations, increases productivity, enhances jobs and labour market accessibility, pens new markets for businesses and enhances supply chain efficiency (see Rodrigue et al., 2017). The concept of transport is very wide and can be considered with many areas of the economy. The basic goal of transport is handling transport needs generated by the economy and the society. The following elaboration focuses on the connection of financial aspects of transport enterprise functioning with changeable retrenchment of macroeconomics.

The economic environment characterizes of many crisis as well as fast changes of competition's conditions create a very dynamic and not stable view of the reality where the strategies of the future development are realized. This unstable, changeable state creates the frames of transport functioning that operates the transport needs of the society. A vigorous transport industry determines the further economic development in Poland. It is crucial to analyse the financial condition of companies providing transport services. The financial result, revenues and costs in view of the high degree of internationalization of the industry are mostly dependent on exchange rates. This dependence is twofold: direct and indirect. The direct impact of the exchange rate results from the costs (see Krawczyk, 2016, pp. 102-110) born in both domestic and foreign currencies. The indirect impact results from the general dependence of the economic situation, in particular the volume of export and import on the level of currency prices.

The transport industry has a very big contribution in the branch structure of the Polish economy and what is more the role of this sector is still growing. Changes in the price of the zloty in relation to other currencies are significant. Among the exchange rates that have the biggest impact on the Polish economy are: PLN/EUR, PLN/USD, PLN/GBP, PLN/CHF. This elaboration combines financial results of transport companies with fluctuating exchange rates. Meta-analyses will cover Polish enterprises from the transport industry in 20102017. The goal of this elaboration is to present the financial result of transport sector enterprises broken down into revenues and costs. The financial result will also be separated for entities employing more than 49 people. The gross turnover profitability will be presented. The exchange rates fluctuations will be shown during the considered period. In the research unit the change dynamics of the presented indicators will be calculated. Moreover, the Persona ratio will verify the dependence of the financial result on the individual exchange rates. The result of the study allows to verify the research hypotheses (described in more detail in the unit of methodology). 
The initial stage of the study begins with the critical analysis of the literature and industry reports. A review of the writing likewise references to observation of business practice, own experiences and thoughts grants to create a theoretical basis for the study of numerical data with the assistance of statistical methods.

The study is based on historical data to identify the relationship of defined variables. The quantitative methods are used to analyse the data. Pearson correlation is a measure of the linear correlation between two variables $X$ and $Y$. It has a value between +1 and -1 , where 1 is total positive linear correlation, 0 is no linear correlation, and -1 is total negative linear correlation.

Article will be divided into following sections: introduction, literature review, research methodology, results, discussions, conclusions. The first part shows the meaning of the transport for the economy and the essence of dependence of the business financial result from exchange rates at the same time confirming the legitimacy of the taken subject. The second part includes the overview on the writing in the field of transport theory and currency rates. The third part describes the methodology of the taken research with the particular emphasis on the correlation study using the Pearson coefficient. The next points presents data and calculates the level of dependence. The later phase interprets the numerical data. The presentation of numerical data in tabular form and graphs can be found in the annex at the end of the publication. The entire study will be closed with a summary.

\section{Literature review}

Movements of people, freight and information have always been fundamental components of the economic and social life of societies (see Rodrigue et al., 2017). Contemporary economic processes have been accompanied by a significant increase in mobility and higher levels of accessibility. Globalization process and international integration of economies create favourable conditions for more dynamic development. Polish economy can be considered as an interesting case study for the proposed scientific problem, as it is the biggest economy in Central Europe (Pietrzak et al., 2017, pp. 190-203).

It has become common to forecast demand for transport of goods due to the increase in the main macroeconomic indicators, in particular GDP. It is done with the assumption that there is a balanced proportion between the intensity of physical production and exchange and the intensity of demand for transport. It is still worth to confront this point of view with the statistical data from the previous periods. This kind of data shows that in many cases the correlation with macroeconomic values and transport is very weak or even negative. The volume of demand for transport is affected not only by the level of physical production and exchange, but also by changes in business, location, optimization of transport and logistics processes, changes in technology and production organization, inventory management and other quantitative and qualitative factors. (Burnewicz, 2017, pp. 7-18). Czech \& Lewczuk (2016, pp. 79-88) 
explore taxonomic and econometric analysis of road transport development in Poland. The results obtained in this research show that there is an interdependence in the area of socioeconomic development in particular voivodships and the level of their road development. The higher are the economic parameters of the related position of a voivodship in the ranking, the higher is the level of road transport development.

Taylor and Ciechanski (2018, pp. 114-122) writes about the transformation of polish transport companies after the year 1989.Their paper seeks to reconstruct post-1989 organisational and ownership transformations in Poland's rail-, road-, and urban-transport companies, as well as those involved in inland shipping. About the development trends of polish transport companies writes Mężyk i Zamkowowska (2016, pp. 83-98; 2015, pp. 3248-3254). Their paper presents the most important factors influencing contemporary changes in transport needs, which include: the progress of globalization and integration, the development of e-commerce and logistics. We can also find there a synthetic statistical profile of transport development in Poland after 2005. They also consider the challenges for the transport industry resulting from globalization. They emphasize that, liberalization and globalization, and consequently, development and development. The diagnosis of the Polish TSL sector announces that it does not fully use its potential. Its development after the year 1989 was dynamic, but now it faces new challenges (Krawczyk, 2018, pp. 447-459).

The transport strand is also investigated from the microeconomic level. The relationship between Net Promoter Score (NPS) and the profitability of transport companies using the Spearman test examines Korneta (2018, pp. 136-148). The study aim was to verify the influence of NPS on the growth and profitability of Polish transportation companies. The findings of this study reject the proclaimed relationship between NPS and growth; hence, in that matter, the results are aligned to criticism presented in literature. The study, however, confirmed a positive and statistically significant relationship between NPS and profitability. Accordingly, the study recommends Polish transportation companies to include NPS in a portfolio of metrics, however, not as a stand-alone diagnostic tool.

Many publication is spared to the topic of currency fluctuation because this topic is interesting from many reasons, both on the level of micro and macroeconomic. About zloty fluctuation and its dependence on European currency, among others, is written by Michalczyk (2011, pp. 120-130). It confirms broad interest in the subject of many researchers. Understanding the dynamic of exchange rates has always been an interesting question in economics and finance. The information carried by such exchange rate signals or variables in our globalised economies is indeed at the crossroad of several other dynamic variables (Ames et al., 2018, pp. 805-831).

Exchange rates are dependent from many macroeconomic factors at the national and global level. Exchange rate factors emerge from economically large regions. Economic size evidently matters in exchange rate determination, 
and possibly in other international asset pricing settings. Empirical research dependencies on the example of dollar and euro confirm the mutual dependence of rates on the global economy. This implies exchange rates are driven by global, US and Euro-zone (Greenaway-McGrevy et al., 2015, pp. 2193-2218).

Chi (2018, pp. 158-169) writes about the relationship between currency exchange rates and maritime trade flows. He analyses the example of Japan and the USA. He concludes that using the perfectly reversible (linear) elasticities of demand could mislead the effects of exchange rate and income changes and result in biased estimation. At the disaggregate level, the asymmetric effects of exchange rate and income changes tend to vary across industries.

Ben Cheikh \& Rault (2017, pp. 2611-2638) study inking exchange rates with macroeconomic factors Their study aims to shed further light on the role of microeconomic factors vs. macroeconomic factors in influencing the extent of the exchange rate pass-through (ERPT). Their findings support the view that the extent of pass-through is comprised of both macro- and microeconomic aspects that policymakers should take into account.

Saha (2017) asks about symmetry and asymmetry of the effect of the exchange rate in his essay. The results of studies show that the effect of exchange rate changes is asymmetric on stock prices. Furthermore, data at the sectoral level for the U.S. stock market to investigate the performance of different sectors due to changes in macroeconomic variables and results show that different sectors react differently to changes in macroeconomic variables and exchange rate changes have asymmetric effects on the stock price indices of different sectors in the U.S.

Many researchers deal with the transport industry and explore it from many points of view. The topic of exchange rates is a very interesting subject and it is an area of many studies. But, there is no publication that presents the research in the scope of correlation between financial results of transport enterprises and exchange rates.

\section{Methods}

The first stage of research, based on the method of analysis and criticism of the literature, will be prepared in the area of the subject taken, including relations between the main concepts. This stage is auxiliary and constitutes a starting point for further research. Later, thanks to the statistical method, the indexes of dependence between the examined values will be estimated (financial result, exchange rates). Article will apply the data of National Polish Bank and the Statistical Office.

The quantitative methods are used to analyse the data. The study is based on historical data to identify the relationship of defined variables. The review carries out at the level of mesoanalysis - transport sector (Borowiecki \& Siuta-Tokarska, 2015, pp. 52-55). The study uses statistical data published by Statistics Poland (GUS, 2018) and National Bank of Poland (NBP, 2018). Publi- 
cations developed by these institutions are highly reliable, and thus the collected research material is credible. Information concerning the financial results of enterprises from the transport sector will be selected from the annual Statistic Poland reports entitled Transport: activity results in the analysed years 2010-2017. The second part of the analysed dependence - the average annual exchange rates will be calculated on the basis of archival data collected by the NBP (2018).

In the assumption of the elaboration four research hypotheses are going to be examined. The first, basic one will qualify the verification of the next three. The following supplements will be subject to review:

- Is there a dependence between financial results of enterprises from the transport sector and exchange rates PLN/EUR, PLN/USD, PLN/GBP, PLN/ $\mathrm{CHF}$ ?

- Is the dependence conditioned by the size of the enterprise?

- The dependence of which of the exchange rate in the analysed period was the strongest and which was the weakest?

- The relation of which of the elements of the financial result (revenues, costs) is the largest?

The specified hypothesis will be verified using a correlation coefficient. Correlation examines the relationships between pairs of variables (see Iwasiewicz \& Paszek, 2004, pp. 135-139). The Pearson correlation coefficient is widely used in this type of relations. Pearson product-moment correlation coefficient is widely used in economics, social sciences, medicine, etc., as a measure of linear relationship between two variable $X$ and $Y$. The mathematical formula for this coefficient was developed by Pearson in 1895.

For each case we must check if the interpretation is in line with the particularities of data and the used model. However, a specific value of Pearson coefficient is difficult to interpret. One of the example gives Stanisz (1998):

- $|r|=0$ - no correlation;

- $0.0<|r| \leq 0.1$ - faint correlation;

- $0.1<|r| \leq 0.3$ - weak correlation;

- $0.3<|r| \leq 0.5$ - average correlation;

- $0.5<|r| \leq 0.7$ - high correlation;

- $0.7<|r| \leq 0.9$ - very high correlation;

- $0.9<|r|<1.0$ - almost full correlation;

- $|r|=1$ - full correlation.

Importantly, we have to be constantly aware of the limitation of any financial model. Correlations may be interpret as strong, weak and negative. This type of rendering is arbitrary and we can not treat it too closely. Moreover, Pearson's coefficient is very sensitive to outliers (extreme). If we have even one of such outliers it can influence our results in a very negative way. No financial model will ever be able to replicate complex economic reality perfectly. However, this does not mean models are useless. 


\section{Results}

The financial reality is extremely complex, with thousands of entities, who may behave irrationally and numerous markets such as equity, fixed income, commodities, foreign exchange, real estate, and more, which are correlated. The study analyses the selected area, which is the result of the activities of Polish enterprises in the transport industry. It makes an attempt to provide a numerical proof of the relationship between the financial result and selected exchange rates.

First, it is worth presenting a numerical exemplification of the growing importance of the transport industry in the Polish economy. GUS (2018) data show that the road transport industry employed 345,000 people. Transport currently produces $5.8 \%$ of the total GDP of Poland, being the third most important branch of the economy: after industry and trade, and before construction. The share of transport in generating GDP in Poland is at a much higher level than in most European countries. The average for the whole Union is just over 2\%, and in large developed countries, such as Germany or France, is on average below $2 \%$ of GDP. It clearly shows that transport has much more significance for the Polish economy than in other European Union countries. In quantitative terms, Polish transport companies begins to dominate in transport.

By analyzing the results of transport enterprises (see table 2) the clear increase is visible, in 2010 it was more than 8147 mil zlotych and in 2017 it was $26650 \mathrm{mln}$ zlotych. This situation presents more than threefold growth over 8 years. Despite temporary declines in income, the turnover in the industry is steadily growing. The highest dynamics was recorded in revenues and costs in 2012 (revenues increased by $20.06 \%$, costs by 13.26\%). Gross turnover profitability rate - being the ratio of gross financial result to revenues also increased from the level of $2.4 \%$ in 2010 to $5.0 \%$ in 2017 . The growth rate of profitability was the highest in 2015 and amounted to $46.67 \%$ (table 3).

The exchange rate of the Polish currency varies, which can be seen in table 1. The highest pound in relation to the zloty is the British pound, its average exchange rate ranged from the lowest - 4.6587 in 2010 to 5.7675 in 2015, so that in the subsequent years after the referendum decision to leave the European Union by the British fell to 4.8595. The smallest fluctuation in the zloty is in relation to the Euro, the lowest level of this exchange rate was 3.9939 in 2010, the highest in 4.3637 in 2016.

After the short analysis of the financial results of Polish transport industry as well as zloty fluctuations the main research part can be instigated. It consists in verification of research hypotheses with the help of Pearson's correlation coefficient. The correlation table 4 for individual rates from the discussed financial values can be found in the annexes.

The outcome of the calculations demonstrates the existence of a relationship between the financial results of the transport industry and selected exchange rates. The strength of the dependency varies depends on the currency selected. 
Assuming the methodological assumption of classification of dependencies according to the Stanisz (1998) scale, the strength of correlation is as follows:

- the financial result and the exchange rate USD/PLN - very high correlation (0.78);

- the financial result and the exchange rate EUR/PLN - high correlation (0.65);

- the financial result and the exchange rate GBP/PLN - weak correlation (0.16);

- the financial result and the exchange rate CHF/PLN - high correlation (0.62).

Exclusive of smaller entities from the study, these employing up to 49 people, the result of the examined dependence is stronger. The result of this part of the study is as follows:

- the financial result for entities employing more than 49 people and exchange rate USD/PLN - very high correlation (0.82);

- the financial result for entities employing more than 49 people and exchange rate EUR/PLN - very high correlation (0.73);

- the financial result for entities employing more than 49 people and exchange rate GBP/PLN - average correlation (0.37);

- the financial result for entities employing more than 49 people and exchange rate $\mathrm{CHF} / \mathrm{PLN}$ - very high correlation (0.83).

It could be expected that the big entities to a greater extent use different tools which should secure them from exchange rate fluctuations. The impact on this effect could have a greater share of large entities in international transport, smaller entities deal with domestic transport, generating revenues and incurring costs in PLN. This claim is, however, anecdotal evidence and is only conclusions based on observation of the economic reality.

The collapse of the financial result into two basic components, revenues and costs, confirms a high dependence on exchange rates and is presented as follows:

- revenues and exchange rate USD/PLN - very high correlation (0.87);

- costs and exchange rate USD/PLN - very high correlation (0.87);

- revenues and exchange rate EUR/PLN - very high correlation (0.85);

- costs and exchange rate EUR/PLN - very high correlation (0.88);

- revenues and exchange rate GBP/PLN - average correlation (0.43);

- costs and exchange rate GBP/PLN - average correlation (0.49);

- revenues and exchange rate CHF/PLN - very high correlation (0.86);

- costs and exchange rate CHF/PLN - very high correlation (0.89).

The correlation is taking shape in a very high level for three rates (dollar, euro, Swiss franc) approaching almost full (range above 0.9).

The last calculation was made in relation to the turnover profitability for entities employing over 49 people. Their result is as follows:

- gross turnover profitability indicator and exchange rate USD/PLN - almost full correlation (0.94); 
- gross turnover profitability indicator and exchange rate EUR/PLN - high correlation (0.74);

- gross turnover profitability indicator and exchange rate GBP/PLN - average correlation (0.48);

- gross turnover profitability indicator and exchange rate CHF/PLN - very high correlation (0.88).

The presented conclusions allow to verify theresearch hypotheses presented in the metodological part. The first one: is there a relationship between the financial results of transport companies and the exchange rates of PLN/EUR, PLN/USD, PLN/GBP, PLN/CHF? It should be unconditionally confirmed. Dependence exists and it is at a high level. The approval of the first supposition gives the right to verify subsequent ones. The second one, if the dependence is conditioned in the size of the enterprise, is verified positively. Enterprises employing over 49 people are to a greater extent under the influence of exchange rates than the general industry entities.

On the basis of the obtained results, the third hypothesis can be settled: the relationship between which of the exchange rate in the period under study was the strongest and which was the weakest? The research allows to state that the US dollar exchange rate has the largest impact on the financial results of the transport industry. However, there is a weak dependency for the British pound.

In case of the fourth research hypothesis: the relation of which part of the financial result (revenues, costs) is the biggest, there is no clear answer. The results show, almost identically, very high correlation of both components in relation to the US dollar, euro and Swiss franc, average in relation to the British pound.

To sum up, the conducted research (by means of Pearson's correlation coefficient) confirms the existence of a relationship between the financial results of enterprises from the transport sector and selected exchange rates. Correlation in all cases rendered to be positive. The level of association varies depending on the currency and the chosen factor.

\section{Conclusion}

The study presented in this publication concerned the importance and development of the transport industry in Polish economy. Both the analysis of the writing and the statistical data show the dynamic development of the industry in Poland after 1989. The question of the financial results of enterprises in the transport sector has been linked to changes in the exchange rate of zloty. The dependence was examined using the Pearson correlation coefficient. The results of the research confirm the existence of dependence.

Literature review shows a large cognitive-research capacity of both the concept of exchange rates and the transport industry. However, literature on the subject has been lacking comparative studies on exchange rate and financial result of a transport company. The problem of measuring the relationship 
between those two factors has a pioneer character. This study fills the gap in this area and proves research hypotheses verified in the study.

The importance of the transport industry (see Rodrigue et al., 2017, pp. 98-115) called by some the barometers of the economic condition is enormous. Transport takes on even more importance in combination with internationalization and globalization processes. Polish transport enterprises successfully undergone a period of economic transformation and at present they perform a significant role in the area of European Union. In the audited period, their financial results increased, from PLN 8 147.1 million in 2010 to PLN 26650 million in 2017 (table 2). Profitability also increased, the gross turnover profitability indicator was $5.0 \%$ in 2017 as compared to $2.4 \%$ in 2010 .

Polish industry is in the greatest dependent on a relation of the zloty to the euro and the US dollar. The exchange rate of the Swiss franc and the British pound are also significant. During the discussed period, the fluctuations of all four courses were important. The EUR exchange rate was the most stable, the lowest average exchange rate was 3.9939 in 2010, and the highest at 4.3637 in 2016.

The conducted correlation control using the Pearson coefficient of these two factors confirms the existence of dependence. This verifies positively the first research hypothesis by opening the possibility of verification of the other three. The study covered four currency exchange rates: USD/PLN, EUR/PLN, GBP/PLN, CHF/PLN. As part of the operating results, the financial outcome of transport companies in total and those employing over 49 people, revenues, costs and the value of gross turnover profitability indicator were checked.

In most cases, the correlation marked by using the Stanisz (1998) scale was high $(0.5<|r| \leq 0.7)$ or very high $(0.7<|r| \leq 0.9)$. The highest correlation, almost complete, was the US dollar exchange rate combined with the gross turnover profitability indicator -0.94 . The lowest - weak $(0.1<|r| \leq 0.3)$ British pound rate with the financial result of all transport enterprises - 0.16. Generalizing, it can be said that the most correlated exchange rate with the financial results of the transport industry is the US dollar exchange rate, whilst the lowest is the British pound rate.

The results of the conducted research on the mezo level and presented in this publication might interest those who manage transport enterprises. Their cognitive value is all the higher because it refers to the simplest factor to assess their activity, which is the financial result. However, exchange rates are an element of daily calculation of both costs and revenues for this industry.

As far as the most widely applied correlation concept in statistics is the Pearson correlation model, the research has some limitations. The reason for the popularity of it is its simplicity and high intuition. However the relationships identified between the exchange rate and financial result of a transport industry can be treated as a starting point for a deeper research and for conducting further discussions in this area. 


\section{References}

Ames, M., Bagnarosa, G., Peters, G.W., \& Shevchenko, P.V. (2018). Understaning the interplay between covariance forecasting factor models and riskbased portfolio allocations in currency carry trades. Journal of Forecasting, 37(8). doi:10.1002/for.2505.

Ben Cheikh, N., \& Rault, C. (2017). Investigating first-stage exchange rate pass-through: sectoral and macro evidence from euro area countries. World Economy, 40(12). doi:10.1111/twec.12499.

Borowiecki, R., \& Siuta-Tokarska, B. (2015). Konkurencyjność przedsiębiorstw i konkurencyjność gospodarki Polski: zarys problemu. Nierówności Spoteczne a Wzrost Gospodarczy, 41.

Burnewicz, J. (2017). Predictability of transport development. Research Journal of the University of Gdańsk: Transport Economics and Logistics, 72. doi:10.5604/01.3001.0010.6872.

Chi, J. (2018). Asymmetric effects of exchange rate and income changes on maritime freight flows between Japan and the US. Transport Policy, 69. doi:10.1016/j.tranpol.2018.05.019.

Czech, A., \& Lewczuk, J. (2016). Taxonomic and econometric analysis of road transport development in Poland: the voivodship approach. Economics and Management, 8(3). doi:10.1515/emj-2016-0026.

Greenaway-McGrevy, R., Mark, N.C., Sul, D., \& Wu, J.L. (2018). Identifying exchange rate common factors. International Economic Review, 59(4). doi:10.1111/Iere.12334.

GUS. (2018). Retrieved 15.11.2018 from http://stat.gov.pl.

Iwasiewicz, A., \& Paszek, Z. (2004). Statystyka z elementami statystycznych metod monitorowania procesów. Kraków: AE w Krakowie.

Korneta, P. (2018). Net promoter score, growth, and profitability of transportation companies. International Journal of Management and Economics, 54(2). doi:10.2478/ijme-2018-0013.

Krawczyk, P. (2016). Optymalizacja kosztów w przedsiębiorstwie transportowym. In S. Kowalska, \& J. Rubik (Eds.), Zarzadzanie kosztami przedsiębiorstwa w kontekście spotecznej odpowiedzialności biznesu. Czestochowa: Politechnika Częstochowska.

Krawczyk, P. (2018). Wyzwania rozwojowe polskich przedsiębiorstw sektora TSL. Marketing i Rynek, 9.

Mężyk, A., \& Zamkowska, S. (2015). Processes of globalization as a challenge to transport. Logistyka, 3.

Mężyk, A., \& Zamkowska, S. (2016). Development trends in polish transport and economic challenges. Optimum: Studia Ekonomiczne, 6(84). doi:10.15290/ ose.2016.06.84.07.

Michalczyk, W. (2011). An overview to the exchange rate stability as a criterion of the accession to the euro zone. Folia Oeconomica Stetinensia, 10(1). doi:10.2478/v10031-011-0013-2. 
NBP. (2018). Retrieved 03.12.2018 from http://www.nbp.pl.

Pietrzak, M.B., Balcerzak, A.P., Gajdos, A., \& Arendt, Ł. (2017). Entrepreneurial environment at regional level: the case of polish path towards sustain-able socio-economic development. Entrepreneurship and Sustainability Issues, 5(2). doi:10.9770/jesi.2017.5.2(2).

Rodrigue, J.P., Comtois, C. \& Slack, B. (2017). The geography of transport systems. New York: Routledge.

Saha, S., (2017). Do exchange rate changes have symmetric or asymmetric effects on stock prices? Unpublished doctoral dissertation, University of Wisconsin-Milwaukee. Retrieved 15.11.2018 from http://dc.uwm.edu.

Stanisz, A., (1998). Przystępny kurs statystyki w oparciu o program Statistica na przyktadach z medycyny. Kraków: Statsoft Polska.

Taylor, Z., \& Ciechanski, A. (2018). Systemic transformation and changes in surface transport companies in Poland: a synthesis after twenty-five years. Journal of Transport Geography, 70. doi:10.1016/j.jtrangeo.2018.05.016.

\section{Acknowledgements}

Author contributions: authors have given an approval to the final version of the article. Authors contributed to this work equally.

Funding: this research was funded by the Czestochowa University of Technology, Faculty of Management statutory sources.

Note: the results of this study were presented at 10th International Conference on Applied Economics Contemporary Issues in Economy (June 27-28, 2019, Torun, Poland). 


\section{Appendix}

Table 1.

Average annual exchange rate of foreign currencies: USD/PLN, EUR/PLN, GBP/ PLN, CHF/PLN in the years 2010-2017

\begin{tabular}{lllllllll}
\hline Exchange rate & 2010 & \multicolumn{1}{c}{2011} & 2012 & 2013 & 2014 & 2015 & 2016 & 2017 \\
\hline USD/PLN & 3.0179 & 2.9636 & 3.2581 & 3.1615 & 3.1537 & 3.7730 & 3.9435 & 3.7782 \\
EUR/PLN & 3.9939 & 4.1190 & 4.1852 & 4.1976 & 4.1845 & 4.1843 & 4.3637 & 4.2583 \\
GBP/PLN & 4.6587 & 4.7463 & 5.1605 & 4.9426 & 5.1919 & 5.7675 & 5.3405 & 4.8595 \\
CHF/PLN & 2.8983 & 3.3474 & 3.4724 & 3.4101 & 3.4453 & 3.9228 & 4.0027 & 3.8364 \\
\hline
\end{tabular}

Source: NBP (2018).

Table 2.

Financial result of the transport industry, selected elements in the years 2010-2017 (in mln PLN)

\begin{tabular}{cccccc}
\hline Year & $\begin{array}{c}\text { Revenues from } \\
\text { total activity }\end{array}$ & $\begin{array}{c}\text { Costs of obtaining revenues } \\
\text { from total activity }\end{array}$ & $\begin{array}{c}\text { Financial } \\
\text { result }\end{array}$ & $\begin{array}{c}\text { Financial } \\
\text { result* }\end{array}$ & $\begin{array}{c}\text { Gross turnover profitability } \\
\text { indicator (in \%)* }\end{array}$ \\
\hline 2010 & 141580.1 & 133433.0 & 8147.1 & 1823.1 & 2.4 \\
2011 & 150499.2 & 149208.7 & 1290.5 & 1913.0 & 2.5 \\
2012 & 180696.8 & 169000.3 & 11696.5 & 2158.9 & 2.5 \\
2013 & 185740.4 & 175790.6 & 9949.8 & 2701.1 & 3.1 \\
2014 & 195770.9 & 185919.0 & 9851.9 & 2766.1 & 3.0 \\
2015 & 203442.4 & 192228.4 & 11214.0 & 4303.2 & 4.4 \\
2016 & 228530.8 & 210144.0 & 18386.8 & 5001.6 & 4.6 \\
2017 & 250229.2 & 223579.2 & 26650.0 & 6161.6 & 5.0 \\
\hline
\end{tabular}

Notes:

* data for entities employing more than 49 people.

Source: GUS (2018).

Table 3.

Multi-base dynamics of selected elements of the financial result in the years 20102017 (in \%)

\begin{tabular}{ccccrc}
\hline Year & $\begin{array}{c}\text { Revenues from } \\
\text { total activity }\end{array}$ & $\begin{array}{c}\text { Costs of obtaining revenues } \\
\text { from total activity }\end{array}$ & $\begin{array}{c}\text { Financial } \\
\text { result }\end{array}$ & $\begin{array}{c}\text { Financial } \\
\text { result* }\end{array}$ & $\begin{array}{c}\text { Gross turnover } \\
\text { profitability indicator* }\end{array}$ \\
\hline $2010 / 11$ & 6.30 & 11.82 & -84.16 & 4.93 & 4.17 \\
$2011 / 12$ & 20.06 & 13.26 & 806.35 & 12.85 & 0.00 \\
$2012 / 13$ & 2.70 & 4.02 & -14.93 & 25.11 & 24.00 \\
$2013 / 14$ & 5.40 & 5.76 & -0.98 & 2.41 & -3.23 \\
$2014 / 15$ & 3.90 & 3.39 & 13.83 & 55.57 & 46.67 \\
$2015 / 16$ & 12.33 & 9.32 & 63.96 & 16.23 & 4.55 \\
$2016 / 17$ & 9.49 & 6.39 & 44.94 & 23.19 & 8.70 \\
\hline
\end{tabular}

Notes:

* data for entities employing more than 49 people.

Source: Own preperation based on GUS (2018). 
Table 4 .

Correlation of selected exchange rates and financial result of transport enterprises

\begin{tabular}{cccccc}
\hline $\begin{array}{c}\text { Exchange } \\
\text { rate }\end{array}$ & $\begin{array}{c}\text { Revenues from } \\
\text { total activity }\end{array}$ & $\begin{array}{c}\text { Costs of obtaining revenues } \\
\text { from total activity }\end{array}$ & $\begin{array}{c}\text { Financial } \\
\text { result }\end{array}$ & $\begin{array}{c}\text { Financial } \\
\text { result* }\end{array}$ & $\begin{array}{c}\text { Gross turnover } \\
\text { profitability indicator* }\end{array}$ \\
\hline USD/PLN & 0.87 & 0.86 & 0.78 & 0.82 & 0.94 \\
EUR/PLN & 0.86 & 0.88 & 0.65 & 0.74 & 0.74 \\
GBP/PLN & 0.43 & 0.49 & 0.16 & 0.37 & 0.48 \\
CHF/PLN & 0.86 & 0.89 & 0.63 & 0.84 & 0.88 \\
\hline
\end{tabular}

Notes:

* data for entities employing more than 49 people.

Source: Own preperation based on GUS (2018) and NBP (2018). 